Pesq. Vet. Bras. 36(5):389-396, maio 2016 DOI: 10.1590/S0100-736X2016000500006

\title{
Spontaneous poisoning by Brachiaria decumbens in goats ${ }^{1}$
}

\author{
Fábio B. Rosa ${ }^{2}$, Mara I.B. Rubin ${ }^{3}$, Tessie B. Martins ${ }^{4}$, Ricardo A.A. de Lemos ${ }^{4}$, Danilo \\ C. Gomes ${ }^{4}$ Rayane C. Pupin ${ }^{5}$, Stephanie C. Lima ${ }^{5}$ and Claudio S.L. Barros ${ }^{4 *}$
}

\begin{abstract}
Rosa F.B., Rubin M.I.B., Martins T.B., Lemos R.A.A., Gomes D.C., Pupin R.C., Lima S.C. \& Barros C.S.L. 2016. Spontaneous poisoning by Brachiaria decumbens in goats. Pesquisa Veterinária Brasileira 36(5):389-396. Departamento de Patologia, Universidade Federal de Santa Maria, Av. Roraima 1000, Camobi, Santa Maria, RS 97105-900, Brazil. Email: claudioslbarros@uol.com.br

An outbreak of Brachiaria decumbens poisoning in goats in the state of Mato Grosso do Sul, Brazil, is described. Out of a herd of about 1,000 goats, seven goats died after showing photosensitivity ( 3 out 7 goats) and icterus (4/7). Other clinical signs included lethargy, dehydration and weight loss (7/7). At necropsy there was either hepatomegaly or liver atrophy; orange, yellow or gray discoloration - were observed in the liver of six goats. Two had accentuation of lobular pattern and punctate, linear or stellar fibrous depressions were randomly distributedover the capsular surface. Macroscopic changesattributedto liver failure consisting of hydropericardium (2/7) and ascites (2/7) were observed. Histologically, there was accumulation of refringent crystals in the bile ducts and infiltration of foamy macrophages in the liver of all goats. Foamy macrophages were also present in the hepatic and mesenteric lymph nodes of two goats. The diagnosis of $B$. decumbens poisoning was based on epidemiology, clinical signs, necropsy findings and histopathology.
\end{abstract}

INDEX TERMS: Poisonous plants, Brachiara decumbens, saponins, diseases of goats, pathology, liver, photosensitization, plant poisoning.

RESUMO.- [Intoxicação espontânea por Brachiaria decumbens em caprinos.] Relata-se um surto de intoxicação por Brachiaria decumbens em caprinos no estado do Mato Grosso do Sul. De um rebanho de aproximadamente 1.000 caprinos, sete cabras morreram após apresentar fotossensibilização (3 de 7 cabras) e icterícia (4/7). Outros sinais clínicos incluíam apatia, desidratação e emagrecimento (7/7). Todas as cabras tinham alteração no tamanho do fígado - cinco estavam aumentados de volume e dois, diminuídos; o fígado

\footnotetext{
${ }^{1}$ Received on August 21, 2015.

Accepted for publication on March 15, 2016.

Part of the requirements for the Doctoral Degree by the first author in the Programa de Pós-Graduação em Medicina Veterinária, major in Veterinary Pathology.

${ }^{2}$ Programa de Pós-Graduação em Medicina Veterinária, Centro de Ciências Rurais (CCR), Universidade Federal de Santa Maria (UFSM), Camobi, Santa Maria, RS 97105-900, Brazil.

${ }^{3}$ Programa de Pós-Graduação em Medicina Veterinária, Departamento de Clínica de Grandes Animais, CCR, UFSM, Santa Maria, RS 97105-900, Brazil.

${ }^{4}$ Laboratório de Patologia Animal (LAP), Faculdade de Medicina Veterinária e Zootecnia (FAMEZ), Universidade Federal de Mato Grosso do Sul (UFMS), Av. Senador Filinto Müller 2443, Campo Grande, MS 79074-460, Brazil. *Corresponding author: claudioslbarros@ uol.com.br

${ }^{5}$ Programa de Pós-Graduação em Ciência Animal, UFMS, Av. Senador Filinto Müller 2443, Campo Grande, MS 79070-900, Brazil.
}

de 6 cabras tinha alteração na cor - dois eram alaranjados, dois amarelados e dois, acinzentados; o fígado de duas cabras tinha acentuação do padrão lobular e outros dois apresentavam depressões fibrosas puntiformes, lineares ou estreladas, brancacentas distribuídas aleatoriamente pela superfície capsular. Adicionalmente, foram observadas alterações macroscópicas atribuídas à insuficiência hepática como hidropericárdio (2/7) e ascite (2/7). Alterações histopatológicas incluíam cristais refringentes nos ductos biliares e infiltrado de macrófagos espumosos no parênquima hepático de todas as cabras. Macrófagos espumosos também foram observados nos linfonodos mesentéricos e hepáticos em duas cabras. 0 diagnóstico de intoxicação por braquiária foi baseado na epidemiologia, achados clínicos, de necropsia e histopatológicos.

TERMOS DE INDEXAÇÃO: Plantas tóxicas, Brachiara decumbens, saponinas, doença de caprinos, patologia, fígado, fotossensibilização, intoxicação por plantas.

\section{INTRODUCTION}

Brachiaria spp. (Poaceae) is an important plant forage for cattle in the Brazilian cerrado. The easy diffusion, high-capacity production of green mass, good adaptation to low fertility soils and growth capacity during most of the year 
makes this grass an excellent source of food for ruminants (Tokarnia et al. 2012). HoweverBrachiaria spp. is toxicto ruminants and resulting losses poses a problem for livestock raising. The main species of cultivated in Midestern Brazil are Brachiaria decumbens, B. brizantha and B. humidicola (Andrade et al. 2004). B. decumbens is the most toxic (Riet-Correa et al. 2011).

Lithogenic steroidal saponins are the toxic principles in Brachiaria spp. and induce crystal formation in the biliary system resulting in hepatogenous photosensitization (Cruz et al. 2000). These crystals have been reported as insoluble salts resulting from the metabolism of saponins in the digestive tract of ruminants (Driemeier et al. 2002). Brachiaria spp. have been associated with photosensitivity and death in cattle (Lemos et al. 1997, Ecco et al. 2004), sheep (Lemos et al. 1996, Brum et al. 2004, Albernaz et al. 2008), goats (Lemos et al. 1998), buffalo (Rozza et al. 2004, De Oliveira et al. 2013) and horses (Barbosa et al. 2006). The clinical and pathological aspects are similar in all species in which the poisoning was documented. The intoxication may occur at any time of year (Souza et al. 2010), but most outbreaks are observed at the beginning of the rainy season when the pasture is greener and lush and when the plants are young, with higher amounts of saponins (Riet-Correa et al. 2011). Sheep and cattle are the species most affected. Sheep are more susceptible than cattle and young animals (calves and lambs) are more susceptible than adults (Riet-Correa \& Méndez 2007). Goats seem to be more susceptible than sheep: in a study where the two species were kept in the same pasture, only the goats got sick (Lemos et al. 1998). Nonetheless, spontaneous poisoningby Brachiaria spp. appears to be rare in goats (Johnson et al. 1999, Lira et al. 2013, Rosa et al. 2013). In Brazil only one report of the disease in goats was found. In these report two outbreaks associated with liver damage and photosensitivityare described (Lemos et al. 1998).

The onset of clinical signs after the ingestion of the plant is variable and dependenton the content of saponins present in Brachiaria spp., usually signs are noticed 7-10 days after animals start grazing the plant (Riet-Correa \& Méndez 2007). Clinically, affected animals show typical signs of photosensitivity including photophobia and photodermatitis characterized by erythema and edema followed by ulcerations and crusting; of the skin of the face, ears, vulva. Poorly pigmented areas are the most affected. Icterus is not always present. Anorexia, depression, prolonged recumbency, weight loss, ocular discharge, hyperemic conjunctive, nasal discharge and progressive weight loss are also observed in cases of poisoning by Brachiaria spp. (Tokarnia et al. 2012).

At necropsy, the main changes are skin lesions such as those describe above, different degrees of icterus and subcutaneous edema. Usually the liver usually is increased in size with a yellowish or orange discoloration an accentuated lobular pattern, the gall bladder is distended and urine darkened by bilirubin (Brumet al. 2007, Castro et al. 2011, Lemos et al. 2011). Histologically there are swelling, vacuolization and individual necrosis of hepatocytes, periportal fibrosis, bile duct proliferation, pericholangitis, cholangitis, and the presence of crystals or negative images of such crystals in the lumen of the bile ducts and occasionally in the cytoplasm of hepatocytes (Riet-Correa et al. 2011, Mustafa et al. 2012). Characteristic foamy macrophagesare described in liver, mainly in the central zones of the lobule, in hepatic and mesenteric lymph nodes of animals poisoned by Brachiaria spp.(Lemos et al. 1996, Riet-Correa et al. 2002, Gomar et al. 2005), spleen (Driemeier et al. 1998, Riet-Correa et al. 2002), and in the mucosa of the small intestine (Riet-Correa et al. 2002).

There is scarce documentation of spontaneous poisoning by Brachiaria spp. in goats in Brazil (Lemos et al. 1998). This study reports a spontaneous outbreak of poisoning by Brachiaria decumbens in goats from state of Mato Grosso do Sul that resulted in death of seven goats. The epidemiological, clinical, necropsy and histopathology aspects of this outbreak are described.

\section{MATERIALS AND METHODS}

The cases described here occurred in a goat herd and were part of a study to determine the causes of death undergoing in goats of this herd. The epidemiological and clinical data were obtained from the owner and with the veterinary practitioner during on-site visits to the farm. Seven goats were necropsied for this study. Fragments of several organs were sampled and fixed in 10\% formalin. Samples were routinely processed for histopathology and stained with hematoxylin and eosin (HE). Fragments of the lung of three goats which developed pneumonia were sampled, stored under refrigeration and submitted for bacterial culture and isolation. The goats were numerical identified through as 1-7.

\section{RESULTS}

\section{Epidemiological and clinical findings}

The outbreak occurred in the municipality of Bandeirantes (latitude $19^{\circ} 55^{\prime} 04^{\prime \prime}$ South and longitude 21'50"West) during the months of May and June 2015. The goats were part of a herd of about a thousand goats of different categories. The farm is exclusively focused on meat production and goats forming the herd are originated from several regions of Brazil, especially the Northeast. The property is divided into 13 lots and goats are raised in a semi-intensive system; they remain in the pasture during the day and are gathered in the evenings to receive supplemental feed. The pasture of each lot consists exclusively of Brachiaria decumbens. The ages of the seven goats were between five months and five years and they were of mixed breeds. Clinical signs developed by goats included anorexia, lethargy, diarrhea, dehydration, weight loss, sternal recumbency followed by lateral recumbency and death. Three goats showed signs of photosensitivity characterized by facial edema, ulcers and crusts on the nose, muzzle and tip of ears, swelling of the vulva and perineum and alopecia in the periocular and perioral regions and in the dorsum.

\section{Pathology}

Necropsy findings included alteration in liver staining, marked dehydration and serous atrophy of fat in all cases. The liver was orange in two goats and two were yellow with accentuation of lobular pattern (Fig.1). One of these four goats had shallow depressions randomly distributed in the 
parenchyma and capsular surface. The gallbladder was distended in these four animals. Two goats had a liver markedly decreased in size, gray and with numerous punctate areas, linear or stellate, depressed and whitish on the capsular surface (Fig.2 and 3). To thecut surface was markedly firm (Fig.4).
Cutaneous lesions, previously described, were observed in three cases (Fig.5 and 6).In the three goats that developed respiratory signs was observed right unilateral suppurative bronchopneumonia characterized by blackening and consolidation of the parenchyma mainly in right cranial lobe with

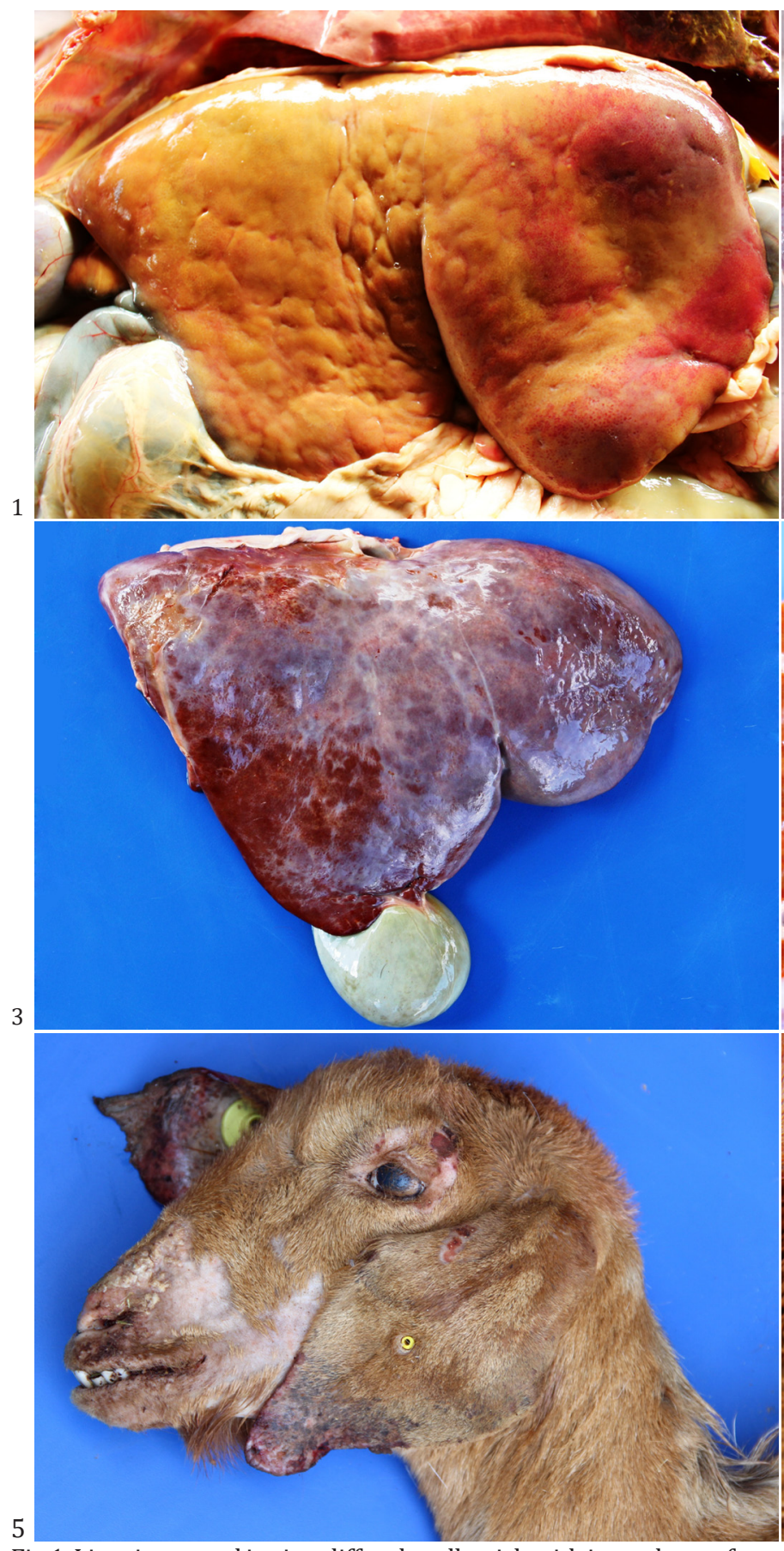

Fig.1. Liver increased in size, diffusely yellowish with irregular surface in Goat 6, succumbed from Brachiaria decumbens poisoning.

Fig.3. Liver decreased in size with marked fibrosis, irregular capsular surface and atrophy of the left lobe in Goat 7, succumbed from Brachiaria decumbens poisoning.

Fig.5. Facial and periocular alopecia, crusting of the muzzle and necrosis of the ear tips in Goat 5, with photosensitization due to Brachiaria decumbens poisoning.

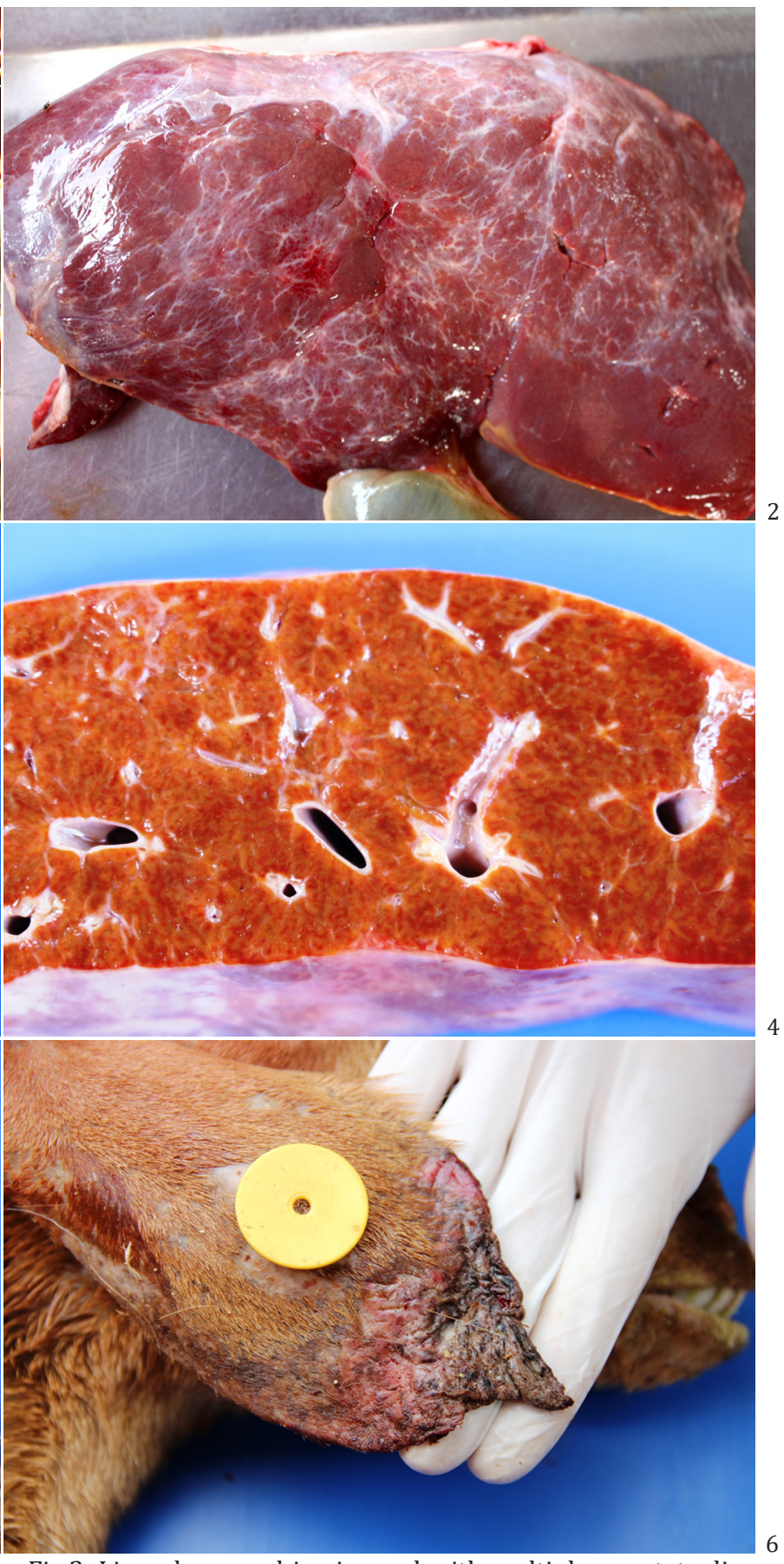

Fig.2. Liver decreased in size and with multiple punctate, linearorstellate, depressed whitish areas on the capsular surface of Goat 1, succumbed from Brachiaria decumbens poisoning.

Fig.4. Cut surface of the liver showing marked fibrosis in Goat 7, ucumed from Brachiaria decumbens poisoning.

Fig.6. Necrosis of the tip of the ear in Goat 5 poisoned by Brachiaria decumbens, with photosensitization due to Brachiaria decumbens poisoning. 


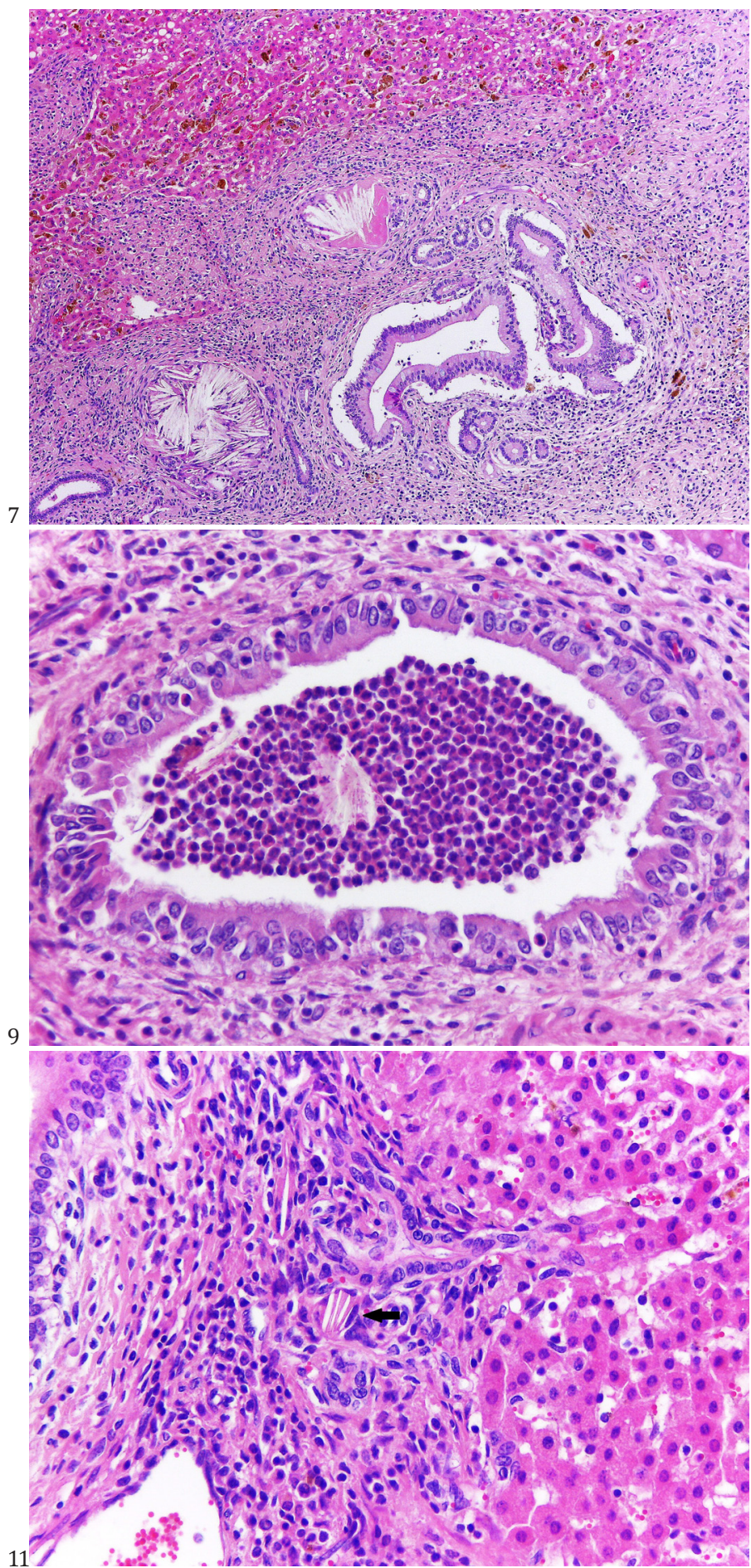

Fig.7. Histology of the liver of Goat 5, succumbed from Brachiaria decumbens poisoning. There is a focally extensive area of severe fibrosis, biliary duct proliferation and mononuclear infiltrate. Some biliary ducts are distended by refringent crystals. HE, obj.20x.

Fig.9. Histology of the liver of Goat 2, succumbed from Brachiaria decumbens poisoning. Biliary duct lumen with numerous neutrophils and a refringent crystal. HE, obj.40x.

Fig.11. Histology of the liver of Goat 3, succumbed from Brachiaria decumbens poisoning. Negative images of the crystals within the cytoplasm of one macrophage (arrow). HE, obj.40x.
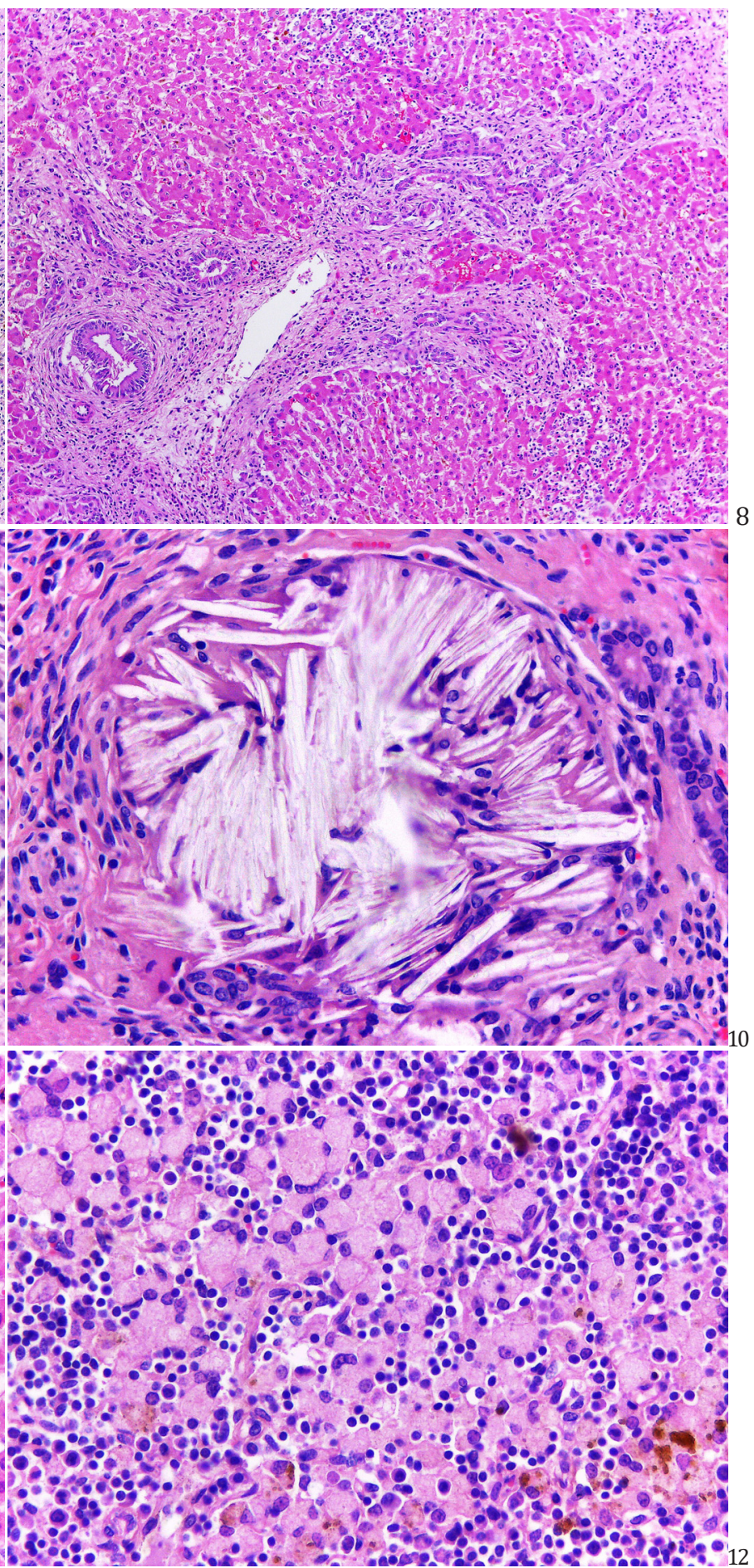

Fig.8. Histology of the liver of Goat 7, succumbed from Brachiaria decumbens poisoning. Bridging fibrosis characterize portal tracts distended by fibrous connective tissue which extends from a portal triad to another portal area, associated biliary duct proliferation. HE, obj.20x.

Fig.10. Histology of the liver of Goat 5, succumbed from Brachiaria decumbens poisoning. There is a biliary duct completely obliterated by refringent crystals or negative images of such crystals. HE, obj.40x.

Fig.12. Histology of hepatic lymph node from Goat 5, succumbed from Brachiaria decumbens poisoning. Numerous foamy macrophages in the lymph node parenchyma. HE, obj.40x. 
adhesion to the costal pleura. Other necropsy findings included hydropericardium (2/7) and ascites (2/7). Histologically, in all cases the main lesions found were limited to the liver and consisted of varying degree of periportal fibrosis and periportal mononuclear inflammatory infiltrate, neutrophilic and lymphoplasmacytic cholangitis and pericholangitis, bile duct proliferation, refringent crystals or acicular negative images of these crystals in the lumen of bile ducts and in the cytoplasm of macrophages (Fig.7, 8, 9, 10 and 11). Foamy macrophages were observed in all cases, randomized, solitary or in groups, predominantly in centrilobular area. Occasionally they were fused to form multinucleated giant cells. Multifocally there were also slight swelling and finely granular cytoplasmic vacuolization of hepatocytes. Individual necrosis of hepatocytes was rare. In goats that developed photosensitive signs, vulva and skin lesions were characterized by areas of necrosis or loss of epithelium with replacement by cellular debris and sometimes by crusts. The dermis and submucosa of the vulva were markedly thickened by edema and neutrophil and also had vasculitis and hemorrhage in the submucosa. In goats that had unilateral pneumonia, this was characterized by extensive multifocal areas of infiltrate of neutrophils and histiocytes that filled the airspaces (bronchi, bronchioles and alveoli). Amid this infiltrated had areas of necrosis, hemorrhage and basophilic coccoid bacterial aggregates. In one case the pleura was markedly thickened by fibrous connective tissue and infiltration of neutrophils and macrophages. Bacteria were not grown in bacteriological examination. This fact is possibly due to antibiotics administered to the goats. In two cases there was multifocal infiltration of foamy macrophages in the hepatic and mesenteric lymph nodes, characterized by large groups of cells with abundant and finely granulated cytoplasm located both in the cortical and medullar zones (Fig.12). Fragments of brain, spleen, kidney and small intestine were analyzed in all cases and did not show lesions. Data of clinical signs and lesions of each goat are summarized in Table 1.

\section{DISCUSSION}

The diagnosis of poisoning by Brachiaria decumbens was based on epidemiological and clinical-pathologic findings, which were very similar to those described in spontaneous and experimental cases of this poisoning in ruminants in Brazil and other parts of the world (Abas-Mazni et al. 1985, Opasina 1985, Lemos et al. 1998, 2011, Brum et al. 2007, Castro et al. 2011, Mustafa et al. 2012, Oliveira et al. 2012). In Brazil, thetoxicosis is often reported in cattle and sheep, but there is only one report of poisoning by Brachiaria spp. in goats. In the latter study two outbreaks of photosensitization associated with cholangitis in goats grazing Brachiaria spp. were reported (Lemos et al. 1998). Reports onthe the spontaneous toxicosisby Brachiaria spp. in goats from other countries are also rare (Abas-Mazni et al. 1985, Opasina 1985).

Beef goat production is a recent activity in throughout the cerrado region, where pastures consist almost exclusively of Brachiaria spp.. Cases of poisoning by Brachiaria spp. are frequent in the region in other ruminant specie, which makes this study of interest for veterinary practitioners, diagnosticians and goat breeders alike. Animals affected by the toxicosis reported in this study were born on the property, i.e., always fed of this plant. However his parents are from the Brazilian Northeast, where there are no reports of poisoning by Brachiaria spp. in goats. Recent studies in sheep show that there is genetic resistance to poisoning (Castro et al. 2011, Riet-Correa et al. 2011), i.e. animals from herds that have never had contact with the Brachiaria grasses are more susceptible than those created in this pastures (Lemos et al. 1996, Castro et al. 2011, Riet-Correa et al. 2011, Oliveira et al. 2012).Perhaps this genetic resistance observed in animals raised in Brachiaria pasture is due to reducing of the mechanism of the toxic effect of the plant such as greatermetabolization capacityand degradation of toxic principle (Castro et al. 2011) and adaptation of ruminal microbiota (Albernaz et al. 2010). Moreover, it

Table 1. Age, main clinical signs and necropsy findingsin seven goats dead from poisoning by Brachiaria decumbens

\begin{tabular}{|c|c|c|c|}
\hline$\#$ & Age & Mainclinicalsigns & Mainnecropsyfindings \\
\hline 1 & 4-year-old & $\begin{array}{l}\text { Dehydration, anorexia, } \\
\text { apathy, weight loss, } \\
\text { diarrhea. }\end{array}$ & $\begin{array}{l}\text { Liver: decrease in size, grayishdiscoloration, multiple punctate, } \\
\text { linear orstellate depressed whitish areas on the capsular surface. } \\
\text { Distended gall bladder. Hydropericardium.Fat deposits: serous atrophy. }\end{array}$ \\
\hline 2 & 3-year-old & $\begin{array}{l}\text { Dehydration, anorexia, apathy, } \\
\text { weight loss, jaundice, } \\
\text { photosensitization. }\end{array}$ & $\begin{array}{l}\text { Liver: increase in size, diffuseorange discoloration, } \\
\text { accentuation of lobular pattern. Distended gall bladder. } \\
\text { Hydropericardium. Fat deposits: serous atrophy. }\end{array}$ \\
\hline 3 & 5-month-old & $\begin{array}{l}\text { Dehydration, anorexia, } \\
\text { apathy, weight loss, } \\
\text { cough, nasal discharge. }\end{array}$ & $\begin{array}{l}\text { Liver: increase in size,diffuse yellowish discoloration. } \\
\text { Unilateral bronchopneumonia. } \\
\text { Fat deposits: serous atrophy. }\end{array}$ \\
\hline 4 & 5-month-old & $\begin{array}{l}\text { Dehydration, anorexia, apathy, } \\
\text { weight loss, cough, nasal discharge, } \\
\text { jaundice, photosensitivity. }\end{array}$ & $\begin{array}{l}\text { Liver: diffuseorange discoloration. Distended gall bladder. } \\
\text { Unilateral fibrinosuppurative bronchopneumonia. } \\
\text { Fat deposits: serous atrophy. }\end{array}$ \\
\hline 5 & 4-year-old & $\begin{array}{l}\text { Dehydration, anorexia, apathy, } \\
\text { weight loss, jaundice, } \\
\text { photosensitization. }\end{array}$ & $\begin{array}{l}\text { Liver: increased in size, diffuseorange discoloration, } \\
\text { accentuation of lobular pattern. Distended gall bladder, } \\
\text { emaciation, ascites. Fat deposits: serous atrophy. }\end{array}$ \\
\hline 6 & 8-month-old & $\begin{array}{l}\text { Dehydration, anorexia, apathy, } \\
\text { weight loss, cough, } \\
\text { nasal discharge, jaundice. }\end{array}$ & $\begin{array}{l}\text { Liver: increase in size, diffuse yellowish discoloration. } \\
\text { Unilateral fibrinosuppurative bronchopneumonia. } \\
\text { Fat deposits: serous atrophy. }\end{array}$ \\
\hline 7 & 5-year-old & $\begin{array}{l}\text { Dehydration, anorexia, apathy, } \\
\text { weight loss. }\end{array}$ & $\begin{array}{l}\text { Liver: decrease in size, grayish discoloration, multiple punctate, } \\
\text { linear orstellate depressed whitish areas on the capsular surface. } \\
\text { Fat deposits: serous atrophy. }\end{array}$ \\
\hline
\end{tabular}


has been proven the existence of individual sensitivity to intoxication (Saturnino et al. 2010, Castro et al. 2011). For these reasons, explained a relatively small number of animals have been affected by intoxication in this property. In addition, there are probably cases of subclinical poisoning or cases where the clinical signs are unnoticed. It is further believed that the poisoning is underreported, as is well known by clinicians and owners and these don't send material for diagnostic laboratories.

Brachiaria poisoning occurs at all times of the year, but most outbreaks have been recorded at the beginning of the rainy season (Lemos et al.1996, Riet-Correa et al. 2011), when the pasture is greener and vigorous and the plants are young, because there are more amount of saponins (Tokarnia et al. 2012). However in a retrospective study of Brachiaria poisoning in cattle there was a greater number of outbreaks in June and July, i.e. in the dry season (Souza et al. 2010). The cases described here occurred in May and June, after months in which there were high rainfall in the region. However it was not possible to associate the outbreak to the recent rains even in the dry season. As for the susceptibility of goats to intoxication, there is disagreement in the literature when compared to sheep. There have been outbreaks where only goats were affected where there were sheep in the pasture (Lemos et al. 1998) and another in which only sheep showed clinical signs (Graydon et al. 1991). In the outbreak reported here it was not possible to determine this relationship, because the property was exclusively focused on beef goat production.

Clinically, the animals intoxicated in this outbreak showed signs similar to those previously reported for goats (Opasina 1985, Lemos et al. 1998) and also to sheep (Mustafa et al. 2012) and bovine (Souza et al. 2010). The clinical course and the age of the animals were quite variable. The most characteristic clinical signs of Brachiaria spp. poisoning is photosensitive, characterized by erythema and cutaneous edema followed by necrosis with detachment of the skin in the most affected areas, which include the depigmented and thinner skin (Tokarnia et al. 2012). Besides edema, erythema and crusting on the face and ears, similarly to sheep, goats which have shown the photosensitization in this outbreak had skin lesions of the vulva and vagina most likely due to sunlight exposure of these sites, as tail is facing upward in goats. Photosensitization was observed in three of the seven affected goats, two of them had a depigmented skin and one had a pigmented skin. It is believed that the pathogenesis of photodermatitis is related to increased skin sensitivity due to the deposition of photodynamic filoeritrin pigment (Tokarnia et al. 2012). Four goats showed no photosensitizing signals. In such cases the major clinical signs were weight loss, dehydration and death in poor body condition that have been assigned to liver failure. A similar clinical presentation characterized by progressive weight loss and death without photosensitivity, has been reported in cattle in pastures of $B$. decumbens (Riet-Correa et al. 2002). In such cases foamy macrophages were viewed in liver, spleen, lymph nodes and small intestine submucosa; so it was suggested that wasting was due to intestinal granulomatous lesion (Riet-Correa et al.
2002). Foamy macrophages were not observed in the small intestine in all the goats of this study. Therefore, more detailed studies are needed to determine the epidemiology and pathology of this form of $B$. decumbens poisoning and its probable relationship with the intake of lithogenic saponins. Three goats showed respiratory signs due to bronchopneumonia, which, in association with liver damage also contributed to the death of the animals. At all cases the bronchopneumonia was unilateral on right side, this kind of presentation is characteristic of aspiration pneumonia. The ruminal contents are highly irritating and cause a fibrinous, necrotizing pneumonia. The right cranial lung lobe tends to be more severely affected because the right cranial bronchus is the most cranial branch and enters the ventrolateral aspect of the trachea (López 2012). The severe malnutrition observed in these goats could have contributed to aspiration pneumonia. Neurological signs due to hepatic encephalopathy and associated with photosensitization caused by Brachiaria spp. ingestion have been described in cattle (Souza et al. 2010) and sheep (Salam-Abdullah et al. 1989). These signs were not observed in this study. There are reports of a subclinical form of the disease in cattle that have less weight gain; this has been related to a negative correlation between the number of foamy macrophages in the liver and body weight in a slaughterhouse (Fioravanti 1999).

The macroscopic and microscopic lesions observed in goats in this study is consistent of Brachiaria decumbens poisoning (Lemos et al. 1998, Riet-Correa \& Méndez 2007, Souza et al. 2010, Mustafa et al. 2012, Tokarnia et al. 2012). The main lesion found in the necropsy is the discoloration of the liver, which can be yellow or orange. Hepatomegaly and distension of the gallbladder can also occur (Riet-Correa \& Méndez 2007). These findings were present in five of the seven goats in this study. In two goats the liver was reduced in size and firm at the cut surface, with multiple punctuate to starry areas in the capsular surface. This pattern had been described in sheep (Tokarnia et al. 2012), but never in goats. Besides the liver lesion, photodermatitis and icterus are also characteristics of Brachiaria poisoning. These lesions coexisted in three goats. Different degrees of icterus are often described in poisoning in ruminants (Riet-Correa et al. 2011). In sheep, icterus is an infrequent finding probably due to acute clinical course of the disease, different from that observed in cattle (Mustafa et al. 2012). Icterus was frequently observed in other outbreaks in goats (Abas-Mazniet al. 1985, Opasina 1985, Lemos et al. 1998). The cause of icterus in this disease is an obstruction of the bile ducts by crystals formed by aggregation of saponins, characterizing a post-hepatic icterus (Cruz et al. 2001). At necropsy of animals had shown clinical signs of weight loss and dehydration there were emaciation, marked serous atrophy of the fat storage and varying degrees of cavity edema. These findings are related to anorexia and liver failure (Driemeier et al. 1999).

The main histological lesions observed in this outbreak was the presence of crystals in the lumen of the bile ducts and in the cytoplasm of hepatocytes, periportal and bridging fibrosis associated with mononuclear cell infiltration, 
cholangitis, proliferation of bile ducts and of foamy macrophages. These lesions were responsible for hepatomegaly and changes hepatic discoloration observed during necropsy. All these findings are typical of Brachiaria spp. poisoning and were also observed in sheep and cattle affected by this toxicosis (Lemos et al. 2011). In two goats of this report, the liver was reduced in size, gray and firm due to the extensive fibrosis observed histologically. In these cases, there was periportal, rather than desiccating fibrosis and there was no megalocytosis, typical lesions of pyrrolizidine alkaloids poisoning (Riet-Correa \& Mendez 2007). Lesions typically induced by saponins are foamy macrophages and crystals in the bile ducts with subsequent cholangitis (Tokarnia et al. 2012). Hepatic fibrosis and proliferation of bile ducts are generic responses to hepatic injury. In cattle, foamy macrophages only indicate that the animal ingested Brachiaria spp. or other plant which contains steroidal saponins and not necessarily what has developed the disease. Foamy macrophages are seen histologically in the liver of healthy slaughtered cattle (Driemeier et al. 1998). Foamy macrophages takes some time to develop in such a time frame that it may not yet possible to be observed in the liver of animals with acute death caused by marked hepatic failurein the absence of photosensitization (Tokarnia et al. 2012). In sheep, foamy macrophages are not present or are few and inconspicuous in a manner that can be overlooked, perhaps due to the greater species susceptibility. Consequently to this greater susceptibility the clinical course is much shorter or the formationof foamy macrophages demands more time in this species (Tokarnia et al. 2012). The accumulation of crystals in the bile ducts in sheep is also inconsistent (Mustafa et al. 2012), unlike what happens in cattle (Souza et al. 2010) and unlike what happen in the goats of this study, which had abundant crystals in the bile duct lumina. In the goats of this study foamy macrophages were very conspicuous. They formed large clusters and were randomly distributed, but were more prominent in the centrilobular zone. It cannot be concluded, however, that goats are more resistant to Brachiaria spp. poisoning than sheep based solely on this information. It is believed that the macrophages turns foamy due to the accumulation of crystals in their cytoplasm. These crystals originate from the binding of the saponin molecule to glucuronic acid which, in turn, binds to calcium salts forming insoluble crystals (Driemeier et al. 2002, Santos 2008). Foamy macrophages are also described in hepatic and mesenteric lymph nodes, spleen and small intestine of cattle (Riet-Correa et al. 2011). In two cases of this report, foamy macrophages were seen in hepatic and mesenteric lymph nodes, in both cortical and medullary zones. Possibly remnants of the substances described above are excreted in the bile and reabsorbed by hepatic and mesenteric lymph nodes (Driemeier et al. 2002).

\section{CONCLUSIONS}

This study emphasizes the aspects of spontaneous poisoning by Brachiaria decumbens in goats, demonstrating that goats are susceptible to poisoning and that grass forage can be an important cause of death in this species.
Goats poisoned by $B$. decumbens may or may not have photosensitivity.

The main clinical signs are dehydration, anorexia, lethargy and weight loss; develop liver color changes - including orange, yellow or gray - and changes in size, with a predominance of hepatomegaly.

There are also characteristic hepatic microscopic changes including crystals in the lumen of bile duct and in the cytoplasm of macrophages, periportal fibrosis associated with mononuclear infiltrates, cholangitis, bile duct proliferation and foamy macrophages mainly located in the centrilobular zone of the liver lobule.

\section{REFERENCES}

Abas-Mazni O., Sharif H., Khusahry M. \& Vance H.N. 1985. Photosensitization in goats on Brachiaria decumbens. Mardi Research Bulletin 13:203-206.

Albernaz T.T., Silveira J.A.S., Reis A.B., Oliveira C.H.S., Oliveira C.M.C., Duarte M.D., Cerqueira V.D., Riet-Correa G. \& Barbosa Neto J.D. 2008. Fotossensibilização em ovinos associada à ingestão de Brachiaria brizantha no Pará. Encontro Nacional de Diagnóstico Veterinário, Campo Grande, MS, p.73-74. (Abstract)

Albernaz T.T., Silveira J.A.S., Silva N.S., Oliveira C.H.S., Belo-Reis A.S., Oliveira C.M.C., Duarte M.D. \& Barbosa J.D. 2010. Fotossensibilização em ovinos associada à ingestão de Brachiaria brizantha no estado do Pará. Pesq. Vet. Bras. 30:741-748.

Andrade R.P., Boas H.D.V., Silveira G.C. \& Paiva L. 2004. Parceria Embrapa-Unipastos e seu impacto na pesquisa e desenvolvimento de pastagens tropicais do Brasil. Matéria técnica, Associação Brasileira de Sementes e Mudas. Disponível em <http://www.abrasem.com.br> Acesso em 25 jun. 2015.

Barbosa J.D., Oliveira C.M.C., Tokarnia C.H. \& Peixoto P.V. 2006. Fotossensibilização hepatógena em equinos pela ingestão de Brachiaria humidicola (Graminae) no Estado do Pará. Pesq. Vet. Bras. 26:147-153.

Brum K.B., Haraguchi M., Lemos R.A.A. \& Fioravanti M.C.S. 2004. Colangiopatia associada a cristais em ovinos mantidos em pastagens de Brachiaria decumbens. Pesq. Vet. Bras. 24(Supl.):14-15.

Brum K.B., Haraguchi M., Lemos R.A.A., Riet-Correa F. \& Fioravante M.C. 2007. Crystal associated cholangiopathy in sheep grazing Brachiaria decumbens containing the saponin protodioscin. Pesq. Vet. Bras. 27:39-42.

Castro M.B., Santos Jr. H.L., Mustafa V.S., Gracindo C.V., Moscardini A.C.R., Louvandini H., Paludo G.R., Borges J.R.J., Haraguchi M., Ferreira M.B. \& Riet-Correa F. 2011. Brachiaria spp. poisoning in sheep in Brazil: experimental and epidemiological findings, p.110-117. In: Riet-Correa F., Pfister J., Schild A.L. \& Wierenga T. (Eds), Poisoning by Plants, Mycotoxins and related Toxins. CAB International, London.

Cruz C., Driemeier D., Pires V.S. \& Schenkel E.P. 2001. Experimentally induced cholangiopathy by dosing sheep with fractionated extracts from Brachiaria decumbens. J. Vet. Diag. Invest. 13:170-172.

Cruz C., Driemeier D., Pires V.S., Colodel E.M., Taketa A.T.C. \& Schenkel E.P. 2000. Isolation of steroidal sapogenins implicated in experimentally induced cholangiopathy of sheep grazing Brachiaria decumbens in Brazil. Vet. Human Toxicol. 42:142-145.

De Oliveira C.H.S., Barbosa J.D., Oliveira C.M.C., Bastianetto E., Melo M.M., Haraguchi M., Freitas L.G.L., Silva M.X. \& Leite R.C. 2013. Hepatic photosensitization in buffaloes intoxicated by Brachiaria decumbens in Minas Gerais state, Brazil. Toxicon 73:121-129.

Driemeier D., Barros S.S., Peixoto P.V., Tokarnia C.H., Döbereiner J. \& Brito M.F. 1998. Estudo histológico, histoquímico e ultra-estrutural de fígados e linfonodos de bovinos com presença de macrófagos espumosos ("foam cells"). Pesq. Vet. Bras. 18:29-34.

Driemeier D., Döbereiner J., Peixoto P.V. \& Brito M.F. 1999. Relação entre macrófagos espumosos ("foam cells") no fígado de bovinos e ingestão de Brachiaria spp. no Brasil. Pesq. Vet. Bras. 19:79-83.

Driemeier D., Colodel E.M., Seitz A.L., Barros S.S. \& Cruz C.E.F 2002. Study of experimentally induced lesions in sheep by grazing Brachiaria decumbens. Toxicon 40:1027-1031. 
Ecco R., Santos Jr H.L., Túry E. \& Jacobina G.C. 2004. Intoxicação crônica por Brachiaria spp. em bovinos. Pesq. Vet. Bras. 24(Supl.):19-20.

Fioravanti M.C. 1999. Incidência, avaliação clínica, laboratorial e anatomopatológica da intoxicação subclínica por esporidesmina em bovinos. Tese de Doutorado, Faculdade de Medicina Veterinária e Zootecnia, Unesp, Botucatu. 256p.

Gomar M.S., Driemeier D., Colodel E.M. \& Gimeno E.J. 2005. Lectin histochemistry of foam cells in tissues of cattle grazing Brachiaria spp. J. Vet. Med. Physiol. Pathol. Clin. Med. 52:18-21.

Graydon R.J., Hamid H., Zahari P. \& Gardiner C. 1991. Photosensitisation and crystal-associated cholangiohepatopathy in sheep grazing Brachiaria decumbens. Aust. Vet. J. 68:234-236.

Johnson E.H., Muirhead D., King G.J., Ochei J. \& Al-Busaidy R. 1999. An abattoir survey of caprine liver diseases in the Sultanate of Oman. Vet. J. 158:216-220

Lemos R.A.A., Salvador S.C. \& Nakazato L. 1997. Photosensitizationand crystal associated cholangiohepatopathy in cattle grazing Brachiaria decumbens in Brazil. Vet. Human Toxicol. 39:376-377.

Lemos R.A.A., Ferreira L.C.L., Silva S.M., Nakazato L. \& Salvador S.C. 1996. Fotossensibilização e colangiopatia associada à cristais em ovinos em pastagem com Brachiaria decumbens. Ciência Rural 26:109-113.

Lemos R.A.A., Nakazato L., Herrero J.R.G.O., Silveira A.C. \& Porfírio L.C. 1998. Fotossensibilização e colangiopatia associada a cristais em caprinos mantidos sob pastagem de Brachiaria decumbens no Mato Grosso do Sul. Ciência Rural 28:507-510.

Lemos R.A.A., Nogueira A.P.A., Souza R.I.C., Santos B.S., Carvalho N.M., Aniz A.C.M. \& Freitas P.C. 2011. Brachiaria spp. poisoning in ruminants in Mato Grosso do Sul, Brazil, p.129-132. In: Riet-Correa F., Pfister J., Schild A.L. \& Wierenga T. (Eds), Poisoning by Plants, Mycotoxins and related Toxins. CAB International, London.

Lira M.A.A., Simões S.V.D., Riet-Correa F., Pessoa C.M.R., Dantas A.F.M. \& Miranda Neto E.G. 2013. Doenças do sistema digestório de caprinos e ovinos no semiárido do Brasil. Pesq. Vet. Bras. 33:193-198.

López A. 2012. Respiratory system, mediastinum and pleurae, p.515. In: Zachary J.F. \& McGavin M.D. (Eds), Pathologic Basis of Veterinary Disease. 5th ed. Elsevier, St Louis.

Mustafa V.S., Moscardini A.R.C., Borges J.R.J., Reckziegel G.C., Riet-Correa F. \& Castro M.B. 2012. Intoxicação natural por Brachiaria spp. em ovinos no Brasil Central. Pesq. Vet. Bras. 32:1272-1280.
Oliveira R.S., Silva R.M.M., Dutra P.A., Ferreira E.A., Pinheiro E.E.G., Macêdo J.T.S.A. \& Pedroso P.M.O. 2012. Intoxicação espontânea por Brachiaria decumbens em ovinos no estado da Bahia. Arqs Pesq. Anim. 1:58-63.

Opasina B.A. 1985. Photosensitization jaundice syndrome in West African dwarf goats and sheep. Tropical Grasslands 19:120-123.

Riet-Correa B., Castro M.B., Lemos R.A.A., Riet-Correa G., Mustafa V. \& Riet-Correa F. 2011. Brachiaria spp. poisoning of ruminants in Brazil. Pesq. Vet. Bras. 31:183-192.

Riet-Correa F. \& Méndez M.C. 2007. Intoxicações por plantas e micotoxinas, p.99-221. In: Riet-Correa F., Schild A.L., Lemos R.A.A. \& Borges J.R.J. (Eds), Doenças de Ruminantes e Equídeos. Vol.2. 3aㅡ ed. Pallotti, Santa Maria.

Riet-Correa G., Riet-Correa F., Schild A.L. \& Driemeier D. 2002. Wasting and death in cattle associated with chronic grazing of Brachiaria decumbens. Vet. Hum. Toxicol. 44:179-180.

Rosa F.B., Caprioli R.A., Silva T.M., Galiza G.J.N., Barros C.S.L., Irigoyen L.F., Fighera R.A. \& Kommers G.D. 2013. Doenças de caprinos diagnosticadas na região central do Rio Grande do Sul: 114 casos. Pesq. Vet. Bras. 33:199-204

Rozza D.B., Seitz A.L., Bandarra P.M., Santos E.O. \& Driemeier D. 2004. Fotossensibilização por Brachiaria decumbens em búfalo. Pesq. Vet. Bras. 24(Supl.):55-56.

Salam-Abdullah A.S., Noordin M.M. \& Rajion M.A. 1989. Neurological disorders in sheep during signal grass (Brachiaria decumbens) toxicity. Vet. Human Toxicol. 31:128-129.

Santos Jr H.L. 2008. Estudo da toxicidade de diferentes estágios de crescimento de Brachiaria decumbens em ovinos. Dissertação de Mestrado em Saúde Animal, Faculdade de Agronomia e Veterinária, Universidade de Brasília, Brasília. 70p.

Saturnino K.C., Marian T.N., Barbosa-Ferreira M., Brum K., Fernandes C.E.S. \& Lemos R.A.A. 2010. Intoxicação experimental por Brachiaria decumbens em ovinos confinados. Pesq. Vet. Bras. 30:195-202.

Souza R.I.C., Riet-Correa F., Barbosa-Ferreira M., Brum K.B., Fernandes C.E. \& Lemos R.A.A. 2010. Intoxicação por Brachiaria spp. em bovinos no Mato Grosso do Sul. Pesq. Vet. Bras. 30:1036-1042.

Tokarnia C.H., Brito M.F., Barbosa J.D., Peixoto P.V. \& Döbereiner J. 2012. Plantas/micotoxinas fotossensibilizantes, p.305-348. In: Ibid. (Eds), Plantas Tóxicas do Brasil para Animais de Produção. $2^{a}$ ed. Helianthus, Rio de Janeiro. 